\title{
Debating Banking in Britain: The Colwyn Committee, 1918
}

\begin{abstract}
By 1918 the British banking system had reached a degree of maturity and concentration, with a small number of large banks dominating the sector. Political concerns about the rise of financial power led to the appointment of the Colwyn Committee to investigate the amalgamations process, and consider the issue of concentration with reference to the role of banking in the economy. In this paper we explore this critical inflection point in British banking history and argue that the Committee’s proceedings reveal that many current concerns about banking correspond to those of a century ago. We also argue that-contrary to some historical interpretation-the Committee did not unequivocally favour financial interests, but rather sought to stabilise organisational change in the sector, and introduce new restrictions on the freedom of banks in respect of amalgamation, as well as supervision and regulation.
\end{abstract}

key words: banking amalgamations; banking regulation; British banking; financial development. 


\section{Introduction}

The link between financial development and economic growth has been widely investigated and most evidence points to a positive causal effect. ${ }^{1}$ Gerschenkron (1962) and Goldsmith (1969) debated the relative merits of bank-based versus marketbased financial systems in financial development several decades ago. More recently Fohlin argued that 'the specific type of financial system or institutions that develop is far less important for economic growth than the development of some wellfunctioning financial system’ (Fohlin, 2016, 426, emphasis in original). ${ }^{2}$ Recent historical evidence similarly indicates that both banks and stock markets contribute to economic growth (for example, Carlin and Mayer, 2003; Levine and Zervos, 1998; Rajan and Zingales, 1998). Nevertheless, the variations in the structure and form of financial services provision - specifically with respect to the financing of industry are often used to express essentialist notions of which is preferable, or better suited, to the promotion of economic growth more generally.

The financial system of the United Kingdom - like that of the United States of America - is generally characterised as stock market-oriented, in contrast to the bankoriented financial systems of France, Germany and Japan (Allen and Gale, 2000; Newton, 2010). The particular combination of stock market capital provision and banking in the UK has been the subject of a long-running and wide-ranging debate about whether the financial sector as a whole performed poorly in its wider economic function of promotion of economic growth (Best and Humphries, 1986; Ingham, 1984; Nicholls, 1988; Peters, 1993). In turn this provokes questions about how a specific financial system developed historically, and the extent to which it emerged or 
was intentionally structured. Richard Grossman identified four themes that shape the historical development of banking: financial and institutional crises, bailouts, periods of amalgamation and merger, and regulation (Grossman, 2010, xviii). All of these elements are relevant to this paper, especially the latter two.

We focus on the British banking system at an arguably critical moment in its historical development. The UK arguably had a highly competitive financial system at the outbreak of World War One and delivered at least broadly comparable outcomes in business finance to Germany (Hannah, 2017, especially 91-95). Table 1 provides some measures of financial development in 1913 and reinforces the view that the financial systems of several major countries were not dissimilar in terms of outcomes and structures. However, by 1918 concerns around amalgamations in British banking led to the establishment of an influential official investigation, the Treasury Committee on Banking Amalgamations (sometimes referred to by the name of its chairman, Lord Colwyn, and hereafter 'the Committee'). The main outcome of the Committee was to check the progress of banking amalgamations, which began in the late eighteenth century, and intensified in the period after 1810, creating the structure of British domestic banking which remains recognisable today. This inflection point is widely discussed in the existing historiography mainly by reference to the Committee's findings rather than its deliberations. We place the Committee's political deliberations into the organisational context of the business/financial history of the period, and explore how that discourse contributed to shaping the subsequent development of the UK financial sector. 
The central contribution of this paper is to contextualise, problematize, and interpret the unpublished evidence presented to the Committee with reference to contemporary concerns relating to the nature, development and future of British banking and the wider financial system. The Committee's terms of reference required it to consider and report on the effect of bank amalgamations on 'the industrial and mercantile community’ and what, if any, legislation or other safeguards should be introduced. These terms of reference raise the question of how the Committee its witnesses interpreted the role of banks in the provision of business finance. In particular, did amalgamations impact on competition so as to create a tension between banks' 'public utility role' and the stability of the financial system? If so, what solutions, if any, could the Committee offer?

The paper is structured as follows. The next section outlines the development of the British banking system in the nineteenth and early twentieth centuries, and considers the amalgamation process that shaped the sector to place the Committee's deliberations in broader context. The third section outlines the background to the Committee, briefly discussing its membership, the witnesses, its proceedings and their outcome. The fourth section addresses the issues raised by witnesses and attempts to place their evidence in the context of academic scholarship on banking, concepts of banking and theories of financial development. The fifth and final section concludes. 


\section{The amalgamation movement and the development of the British banking system}

In the late nineteenth and early twentieth centuries British banking was subject to general corporate law but otherwise essentially unregulated. Banks were predominantly limited liability companies, there was no deposit insurance, there were no ratio-based capital or liquidity regulations, and there were no limits on branching or mergers and acquisitions. Against the background of the gold standard with freedom of capital movement, and a largely passive Bank of England, bankers operated without intrusive regulation (Capie, 2016).

Victorian banks developed significant branch networks before 1880 but these were not national (Barnes and Newton, 2018). Sykes summarised the perceived advantages of local decision-making: 'the provinces have the benefits derived from a management working in the midst of provincial and local conditions, maintaining responsive and intimate touch with industrial changes’ (Sykes, 1926, 189). Histories of British banking typically describe a system with lending decisions based on borrower reputation and the availability of a broad range of collateral rather than detailed analysis of prospects, loan characteristics, and client distress (Capie and Collins, 1999a and 1999b; Collins and Baker, 2003). This system evolved through amalgamations from the late eighteenth century onwards from one with hundreds of unit banks, unable to expand because of limiting legislation removed in the first half of the nineteenth century, into a highly concentrated system. ${ }^{3}$ 
The periodisation of the amalgamation movement owes much to the classic work by Sykes (1926). In identifying 1825 as the beginning of the period, Sykes was essentially correct. Although the population of British banks began to decline from its peak in 1810, the process of amalgamation began in earnest only in the 1820 s (Garnett, Mollan and Bentley, 2015; 2017). ${ }^{4}$ Figure 1 indicates that there were in broad terms four phases of heavy amalgamation. The first began around 1825 and ended in the early 1840s. The second began around 1854, terminating in the late 1860s. The third, and most significant, began in the early 1880s and continued until the outbreak of World War One in 1914. The final, less significant phase began around the end of the war in 1918 and terminated, as Sykes suggests, around 1924.

\section{INSERT FIGURE 1 HERE}

Figure 2 shows that the population of British banks (in comparison with 1810-1924) was broadly stable between 1924 and 1987 when it again began to decline, although there is evidence of population instability from the 1960s onwards when measured as the year-on-year change in the population. What is incontrovertible, however, is that the end of the amalgamation movement as a secular trend in the population of British banks was followed by about half a century or so of relative population stability from the interwar period until at least the 1960s, and arguably until the 1980s. This highlights the importance of the policies that stem from the Committee, and brought to a close a period of profound consolidation in British banking.

\section{INSERT FIGURE 2 HERE}


Figures 3 and 4 show that the amalgamation process during the 40 years or so preceding the Committee was also a process of creation of new banks, and failure of existing banks. Between 1880 and 1918 there were 382 mergers between banks, 599 bank failures, and 251 new banks created. These individual events drove fundamental trends in the overall banking population, notably the elate-nineteenth century emergence of the large retail banks and the later dominance of the Big Five, which had grown through amalgamation (Capie and Rodrik-Bali, 1982). For example, Barclays emerged through the 1896 merger of 12 private banks, and expanded its geographical footprint into the country's industrial areas through later amalgamations (Ackrill and Hannah, 2001, 55-58, 60-61). Another of the Big Five, the Midland, illustrates the relative importance of amalgamations and organic growth through branch openings. From 1880 to 1919 the Midland added 921 branches through amalgamations against 536 through new branch openings, with only 16 branch closures in the period (Crick and Wadsworth, 1936, 333). Concentration in the share of bank deposits and branch numbers increased considerably between 1910 and 1921 (see Table 2), especially through several large amalgamations in 1917 and 1918 (Alhadeff, 1968, 244-246; Capie and Rodrik-Bali, 1982; Turner, 2014, 43).

\section{INSERT TABLE 2 AND FIGURES 3 AND 4 HERE}

This process created banks with large branch networks and dominant market shares. These banks were well-diversified geographically and across different sectors of the economy, and their asset structures had become more liquid and conservative with a gradual shift to lower capital ratios with more (notionally short-term) overdraft lending, tougher lending terms, higher cash balances, and greater holdings of high 
quality investments (Baker and Collins, 2002; Collins and Baker, 2001a; 2001b; 2003). Lending power and decision-making were generally concentrated in these banks' head offices, which had gravitated to London even if some had origins in the provinces. $^{5}$

Historians have tended to focus on two aspects of increased concentration in British domestic banking: the potential negative impact on competition and customers, particularly small and medium-sized enterprises and innovative businesses; and the potential positive impact on stability. ${ }^{6}$ The alleged failings, together with the failure of these banks, the Bank of England, and government to facilitate industrial restructuring, are central to some versions of the 'declinist' narrative on British economic history (Best and Humphries, 1986; Elbaum and Lazonick, 1984, 1986; Tomlinson, 2009). Others contest these claims and argue that these criticisms and the differences between British banks and those elsewhere, particularly in continental Europe, have been exaggerated, and that the banks could claim that their role in the provision of finance was expected to be limited (Ackrill and Hannah, 2001, 93-95; Collins, 1998; Newton, 2003; and Ross, 1990; 1996).

The latter stages of the amalgamation process aroused popular fears of a 'Money Trust' (i.e., the control of the financial system by elite interests, concentrated in an oligopoly made up of a small number of banks), partly influenced by debates on banking in the US following the 1907 financial crisis. ${ }^{7}$ Examination of the trend in the UK banking population offers some insight into the reasonableness of this concern. Figure 5 shows two fitted lines, one fitted to the real population, and the other to a linear trend line based on the consolidation rate in the population as a whole measured 
from its peak in 1810 to the point of the Committee's deliberations in 1918. This fitted linear trend line indicates that the population of UK banks would have become very small by the 1950s. This crude counter-factual device does not 'predict' what would have happened without the Committee. Rather, it shows the banking sector population demographic context which the Committee faced -the trend was towards continued consolidation through amalgamation - and that concerns about a 'Money Trust' were not unreasonable when viewed from this perspective.

INSERT FIGURE 5

\section{The Committee}

Public and political disquiet at the prospects of further consolidation in the sector led the government to appoint the Committee on 11 March 1918. The majority of the Committee’s 12 members and 22 witnesses were elite bankers and businessmen. The chairman Lord Colwyn was a businessman and banker. ${ }^{8}$ Other members included the Governor of the Bank of England, Lord Cunliffe, several bank chairmen or directors, a merchant banker, and several businessmen and industrialists (see Table 3). The witnesses were more mixed, with nine joint-stock bank directors, a variety of other representatives of the financial community, a handful of other businessmen of various types, two economists, one an academic and the other a civil servant, and, intriguingly, the Fabian socialist Sidney Webb (see Table 4). The process by which witnesses were selected is unknown. ${ }^{9}$ The mix of Committee members and witnesses appears cosy and conflicted by modern standards. Several members (Cunliffe, Beckett, Gibbs) and witnesses (Addis, Farrer, Inchcape) were simultaneously sitting 
together as members of the Committee on Currency and Foreign Exchanges after the War, chaired by Cunliffe. ${ }^{10}$ The witnesses Addis, Bell and Beaumont Pease were faced by their own bank chairmen (Keswick and Vassar-Smith) as members of the Committee. $^{11}$

On 1 May 1918, the Committee published a short report, heavily influenced by the witnesses’ oral evidence. Although the report has been referred to widely in the historical literature, only a handful of scholars appear to have consulted the transcripts of evidence (Carnevali, 2005; Grossman, 1999; Kynaston, 1999; Sayers, 1976). One of these, Francesca Carnevali, characterised the Committee as follows: 'financial interests set up the committee and shaped the direction of its investigation. Bankers were asked by bankers whether bank amalgamations should be allowed to continue' (Carnevali, 2005, 19). Thus Carnevali effectively argues that the Colwyn process was fundamentally flawed, having been captured by banking interests which would resist meaningful change. We argue, however, that this interpretation fails to acknowledge the many insights the evidence offers on the nature and structure of contemporary banking and the British financial system more generally, as well as the outcome of the Committee.

\section{INSERT TABLES 3 AND 4 HERE}

The Committee's report noted that it was '... forced to the conclusion that the possible dangers resulting from further large amalgamations are material enough to outweigh the arguments against Government interference ... and some measure of Government control is essential' (Treasury Committee on Bank Amalgamations, 
1918, 7). The Joint Stock Banks (Amalgamation Control) Bill was drafted in 1919 to require government approval for future changes of ownership and control in banking, but no legislation was passed. ${ }^{12}$ However, the mechanism proposed in the draft Bill was introduced on a non-statutory basis: an Advisory Committee on Bank Amalgamations was appointed in May 1919 by the Chancellor of the Exchequer, Andrew Bonar Law. This committee had two members: Colwyn (as 'commercial representative') and Lord Inchcape, a shipping magnate, director of one of the Big Five, the National Provincial, and witness to the Committee (as 'banking representative’). ${ }^{13}$ The Committee witness Sir James Hope Simpson appears to have provided the idea for this advisory committee when he advocated 'a confidential body' to judge amalgamations on merits rather than by rules.

Despite the failure to legislate on amalgamations, official opinion was resolutely opposed to further domestic expansion by the Big Five and amalgamations between members of the London Clearing House, and official policy thwarted various transactions, although several amalgamations in progress when the Committee was appointed were allowed without intervention. ${ }^{14}$ Nevertheless, the keenness of two of the Big Five, Barclays and Lloyds, to test the boundaries of the restrictions greatly irritated Cunliffe’s successor, Montagu Norman, who was particularly concerned about the possibility of contagion from their expanding international activities. ${ }^{15}$

\section{The Evidence}

Many of the questions on which the Committee heard evidence, such as the relationship between competition and financial stability and the merits of geographic 
spread, continue to attract the interest of economists. ${ }^{16}$ Witnesses ranged beyond the Committee's terms of reference in the breadth of issues they addressed: the implications of amalgamations for customers large and small, from local to international; the size and number of banks needed to ensure effective competition; the impact of amalgamations on branch networks; their impact on capital levels in banking, and hence financial stability; the belief of some witnesses that British banks needed to amalgamate in order to compete with other large international banks; the implications of amalgamations for the state, including pressures to assume a larger role in banking, to intervene in the affairs of struggling banks, and the possible nationalisation of banks; and comparisons between the British financial system and those of other countries, notably Germany, the US and Canada. We address these issues below.

\section{The rationale for bank amalgamations}

Banking literature identifies offensive and defensive motivations in banking mergers and acquisitions. Foremost among these is that amalgamations offer the easiest way to expand geographical coverage and establish branch networks (Dymski, 2012, 572). This view is consistent with the suggestion that British banks found amalgamation an advantageous way to expand (Garnett, Mollan, and Bentley, 2015). The literature considers amalgamations as broadly acceptable if the banking market remains contestable and stability is preserved (Dymski, 2012).

For the most part the evidence of the Committee's banking witnesses is consistent with this literature. These witnesses favoured amalgamations and saw no reason to 
make them more difficult. Ford Darling suggested several motives for the proposed merger of his own bank with the London, City and Midland: its lack of geographical spread, its under-representation in industrial centres, the cost of opening branches, and its lack of foreign business and infrastructure to support it. Hambling considered it easier for a bank to amalgamate with another than to establish new branches.

Drummond Fraser believed that amalgamations offered the possibility of economies of scale and supported those that did not involve geographical overlaps of branches or decrease the ratio of paid-up capital to deposits. The non-banker Cowdray felt that bigger banks were able to draw on larger pools of management talent. Other justifications for amalgamations are considered below.

The Committee's report focused heavily on the changing nature of amalgamations, adopting a distinction made principally by the economist Foxwell. He identified three types: those between small unit banks within regions, which he saw as positive in terms of risk-spreading; those between larger banks (possibly created through the previous type) in different regions to achieve 'national' coverage, which he again favoured as spreading risk geographically and by industry of borrower; and finally those of already-large banks with some degree of national coverage, which he saw negatively as reducing competition.

\section{The need for big banks}

Several witnesses discussed the need for large banks, with two strands to this argument: firstly, the necessity of large banks to accommodate the needs of individual customers; and secondly, the need for scale in banking to support economic 
development. Ford Darling cited the business needs of large customers as a reason for his bank’s planned amalgamation, although it had never yet struggled to accommodate these needs. ${ }^{17}$ Several non-banking witnesses accepted the need for scale in banking. Courtney Johnston favoured amalgamations in principle, not only of banks, as 'absolutely essential' to be able to compete. Selfridge argued that US trusts '... have been of the greatest possible assistance to the States ...', and advocated what we might contemporarily describe as distinctly ‘Chandlerian' views on the desirable scale and scope of banking enterprises: 'It seems to me that all our businesses should be bigger in this country ... If you are going to put out a fire you are going to the biggest reservoir for your water. You do not want a lot of little reservoirs'. Cowdray considered that a contractor such as Pearson benefitted from using bank-provided project finance before floating securities in completed and proven projects. He argued that small banks were less useful for this purpose: big banks were better able to assess such projects, whereas smaller banks were more inclined to show favoritism to certain customers. He considered that British banks needed to grow to match the size of the largest US banks and agreed when Colwyn asked whether the country had lost business in, say, 'the East and South America - because our banks have not been large enough to deal with it?' Foxwell thought that the size of banks in countries such as France and Germany ' ... makes it necessary, I think, that we should have in this country very large and powerful banks, but how large and how powerful, of course, it is impossible to lay down a priori'. His argument was echoed by Holden who considered amalgamation 'is the only means of obtaining individual Banks of a size and power at all commensurate with those now being formed or developed in America and Germany’. He argued that large banks would help maintain London’s importance 
as a financial centre, even though the UK's population was smaller than those of Germany and the US.

\section{'Too-small-to-survive' banks}

The two witnesses from Lloyds Bank, Bell and Beaumont Pease, discussed the weakness of small local banks. Bell had been at the 11-branch Liverpool Union Bank, which he claimed was sound but was forced to amalgamate with Lloyds in 1900 due to the seasonality of its business in which customer needs would exceed its deposits available to lend and individual customers could borrow in excess of the bank's capital. ${ }^{18}$ The bank therefore faced the dilemma of turning away sound business from good customers or amalgamating with a larger bank. He claimed that all Liverpool's local banks were under similar strain 'until the big joint stock banks came into the city and brought resources from all over the country'. Purely local mergers would not have solved the problems of seasonality and narrowness of the deposit base.

Holden described his bank’s amalgamations in Liverpool, Manchester and Oldham, and maintained that all had contributed positively to competition, stability and lending in these locations. The London banker Ford Darling presented a different argument: for all but 'three industrial centres' in which his bank was present, 'country branch' deposits exceeded advances, so its head office provided profitable investment outlets for surplus funds. Hambling similarly considered '... that banks should become national ... [and] operate in all areas. ... they should be able to collect their deposits where deposits can be collected and ... they should be able to lend them where 
commerce wants them'. The Liverpool banker Hope Simpson also favoured amalgamations of regional banks 'into’ London. ${ }^{19}$

Bell described a small proportion of Lloyds' amalgamations as 'rescues' and Beaumont Pease went further, claiming some were with insolvent banks. Sayers (1957, 256-257) offers some support for this view, identifying two 1902 acquisitions, the Bucks and Oxon Union Bank and the Cornish Bank, as financially weak. Holden appeared to support the view of Bell and Beaumont Pease. He highlighted that there had been very few bank failures in the period 1900-1913 and linked this to the willingness of the larger banks to 'immediately take up [a weak bank] and prevent disaster' through amalgamation or some other form of support. Holden offered only two specific examples where banks worked together to prevent crisis: the cases of Barings in 1890 and the Yorkshire Penny Bank. ${ }^{20}$

The evidence of Drummond Fraser, in his ' $25^{\text {th }}$ year in Manchester in a managerial capacity', contrasted, and in some respects contradicted, that of the other bankers. He claimed never to have been in the position of being unable to accommodate customers' requirements for advances. He noted that customer and shareholder objections had defeated two proposed combinations between Manchester and London banks and anticipated similar objections to other such proposals. ${ }^{21}$

\section{Lending practice, local banks and competition}

Addis doubted that amalgamations offered customers greater access to credit and thought they created the potential for reduced competition. But the banking witnesses 
generally maintained that post-amalgamation practices were unchanged from earlier banking arrangements. Holden argued that each of his own bank's amalgamations had increased lending, quoted statistics on its lending to the 'small man', and maintained that 'there is no trouble whatever in the small man getting accommodation'. Bell offered to produce extensive evidence of 'uncovered' (i.e. unsecured) lending to small traders and Beaumont Pease provided an extensive commentary on lending practice in private banks versus joint-stock banks, claiming the latter lent no less, and sometimes more, liberally at local level. Ford Darling claimed that his own bank’s lending to smaller customers would be unaffected by its proposed amalgamation as '... our managers have got their discretionary limits, which they use without reference to Head Office at all, for the smaller advances'. In contrast, Inchcape thought that '... I do not think the banks compete very much with each other. I will tell you what they compete in ... is mostly in civility to their customers'. A non-banking witness, Courtney Johnston, thought that 'In the old days the private banker knew the local people, and the local industries and helped them'.

Beaumont Pease claimed that where amalgamations reduced the number of banks in a town or district other banks opened new branches. Bell used the example of Liverpool to illustrate his claim that amalgamations increased competition even if there were fewer banks - small local banks tended to 'live together in the greatest amity' but larger banks were more competitive. Ford Darling thought that in places such as Newcastle there were sufficient banks to ensure competition despite the overlapping branch networks of amalgamating banks. 
In Manchester Drummond Fraser felt well able to compete with London banks. His customers wanted 'the real personal, sympathetic touch ... the close personal touch ... [not] based on the inelastic stereotyped rules necessary under a London control'. He claimed to have acquired numerous sound business customers offering security for loans but unwilling to offer the personal guarantees sought by London banks. Equally, he was willing to lose business to London banks when only very fine margins were available. Webb was sceptical of the value of the 'personal touch' in banking as borrowers formed only a small proportion of customers; the 'personal touch' was irrelevant to the vast majority of depositors.

The claims of these witnesses in relation to the effects of amalgamations on competition can be related to recent literature. Hannah details intense pre-World War One local competition in financial services in the city of Oxford (Hannah, 2017, 7983). Braggion, Dwarkasing and Moore (2017), however, find that amalgamations reduced competition: borrowers of comparable quality in counties with higher concentration in banking received smaller loans and posted more or higher quality collateral.

\section{Concentration, competition and state control}

Simpson argued that '.. the public is, on the whole, better served by banks today than it was when there was a large number of small banks'. He was supported by other bankers, most robustly by Holden in a lengthy opening statement. Opinions on the number of banks necessary to secure effective competition varied: Cowdray suggested five or six; Ford Darling thought ten; Foxwell thought that 'You can have just as keen 
a competition between three separate interests as between 30'. He was relaxed about competition in London given the presence there of foreign banks but thought it preferable to avoid amalgamations which created banks with more than $£ 250 \mathrm{~m}$ in deposits. Holden specified no number, merely stating that there should be a 'sufficient number of powerful Banks to ensure free competition'.

Goodwin’s Co-operative Wholesale Society’s Bank acted for the Co-operative Movement and did not compete directly for commercial banking business. It did, however, use other banks as agents and he considered further amalgamations could be detrimental to his own bank's interests. Goodwin articulated a point made by several witnesses of different persuasions: ‘... the very fact of the banking business of the country getting into a few hands will ... make it all the more easy for a transfer to State control'. Addis thought that continuing amalgamations encouraged socialists to counter the too-big-to-fail problem: 'No Government, obviously, could afford, for National reasons, to allow one of those banks to become insolvent. From guarantee to control is only a step, and from control to Socialism is only one step more removed'.

The only socialist witness, Webb, faced sceptical but respectful questioning. ${ }^{22} \mathrm{He}$ viewed deposit banking as a natural monopoly or oligopoly in that the fewer banks existed, the less inclined depositors would be to 'run' on an individual bank. He thought that the banks would bring nationalisation upon themselves by pursuing amalgamations which would lead to '... too perilous a power to remain in the hands of private persons for private purposes’. The logical solution was for a single bank 'under public control'. He declined to specify any particular form of public ownership saying 'I should put it into the hands of the community', but defended the Labour 
Party against assertions that it advocated nationalisation without compensation. He confirmed bank shareholders should be bought out on 'quite equitable terms' with ‘full and complete compensation'. In response to Keswick’s question '... where is nationalisation to stop', Webb replied: 'I should be sorry to put a limit to it, because we are only at the beginning of eternity. I cannot say where it would stop'. ${ }^{23}$ Other Committee members (Manville and Purcell) pressed Webb as to why the state should take on banking risks. In response he cited the Commonwealth Bank of Australia as an example of state involvement in banking and argued for separation of the deposittaking and lending functions; the state should take deposits and lend or provide capital to financial corporations to undertake business lending.

\section{Attitudes to regulation}

Witnesses' attitudes to regulation varied, with some in favour and others deeply opposed. Cowdray proposed legislation to require banks to report to the Board of Trade any actual or contemplated anti-competitive arrangements. Farrer thought that amalgamations should have been deferred during wartime and had tried to persuade the Board of Trade of this. Stoll advocated safeguards against the excessive power of banks. Courtney Johnston argued for safeguards around banking to prevent local funds being used to finance 'foreign competitors'. Webb, however, thought that legislation to control amalgamations would be ‘sham'.

Some witnesses stressed the importance of transparency. Drummond Fraser called for transparency of capital ratios and advocated monthly publication of uniform balance sheets. Flux discussed the nature and regulation of banking in Canada, noting 
transparency through publication of shareholder lists, monthly accounts, and loans to directors and businesses connected to them. He also detailed Canadian regulation of bank amalgamations, noting that the 1913 Banking Act required the authority of the Minister of Finance for an amalgamation and gave shareholders the right to appoint an auditor from a panel of 40 nominated by the general managers of all banks, although external auditors were assumed to be less effective monitors than insiders due to their lack of familiarity with a bank’s affairs.

Foxwell thought legislation and government control over banking would be too rigid. Other witnesses objected more strongly. Hambling was deeply distrustful: 'I hate competent Government Authorities. I have the strongest possible objection to Government interference because from my short experience I find they do not exercise them [sic] very wisely. I think banks can do their own business better ... ${ }^{24}$ Inchcape expressed similar views: 'I have a very strong objection to Government Control. I think the less Government interferes with the business of the country the better'.

\section{Banks' capital structures}

Discussions around contingent capital or extended liability have revived in recent years as part of the response to twenty-first century financial crisis, with economists arguing for a form of capital which would 'bail in' shareholders in the event of distress, and therefore provide disincentives to excessive risk-taking (Chennells and Wingfield, 2015; Turner, 2014). In theory such a mechanism still existed in 1918 and later. Banks with limited liability typically issued at least some shares that were 
partly- rather than fully-paid up, with the balance callable at directors' discretion. Banks sometimes also issued shares with reserve liability, callable only in a windingup, similar to extended liability regimes in US banks (Grossman, 2010, 237-240). These arrangements supposedly protected depositors by providing resources which could be called up to boost banks’ capital positions. Share classes which were not fully paid and/or carried reserve liability typically carried rights to higher dividends to compensate for the (at least notional) risk that the uncalled elements would be called up. These contingent capital arrangements appear to have reduced risk-taking by British banks before World War One, particularly among banks with higher leverage (Grossman and Imai, 2013). The Committee’s report, however, noted that amalgamations had weakened capital ratios, and that uncalled capital in particular had been reduced, '... with substantial benefits to shareholders ... purchased at the expense of some of the security of depositors’ (Treasury Committee on Bank Amalgamations, 1918, 6). ${ }^{25}$

Many witnesses spontaneously commented on, or were questioned about, the effect of amalgamations on bank capital. Holden actually claimed that amalgamations increased capital. Foxwell noted that paid-up capital had fallen in relative terms, with deposits and total liabilities more than doubling in the preceding decade, with no increase in capital. Addis also noted that amalgamations sometimes eliminated shareholders' uncalled liability, which he considered disadvantageous. He also claimed that, in contrast to British amalgamations, German bank amalgamations increased paid-up capital. 
Ford Darling regarded uncalled capital as a disincentive to shareholders in banks in general and a constraint on his own bank's ability to amalgamate with others. His bank’s proposed amalgamation with the London City and Midland Bank would reduce its uncalled liability to $£ 38$ per share from $£ 85$ per share which he considered beneficial to his shareholders. Inchcape told the Committee that in his bank every share transfer came before a board committee where ' ... the standing, employment, and responsibility of the transferee are considered' to ensure that calls on uncalled capital could be met. He also likened the possible impact of such calls to the 1878 collapse of the unlimited-liability City of Glasgow Bank which prompted banks to rush to limited liability status (Acheson.and Turner, 2008; Button et al., 2015). Foxwell was sceptical of the ability of banks to call up uncalled capital. He also identified the moral hazard problem in a concentrated banking sector, linking the toobig-to-fail argument to the decline in capital ratios:

... institutions of a certain size are "too large to let go". It inspires the customers with confidence when a bank reaches a certain size; they say that whatever the state of things this bank will not be allowed to fall: a crash would carry the market away. I confess I think this rather an unfortunate presumption, though it may be a sound one, because I believe it is partly responsible for the very slender reserves which our banks carry, and the very small proportionate capital. 


\section{International comparisons and 'Money Trust' claims}

Witnesses made some comparisons to the banking systems of other countries, generally the US, Canada, France, and, most often and usually favourably, Germany. Hambling praised the German system and claimed '... it will be necessary after the war to have these big institutions [i.e. banks similar to Germany's Grossbanken] to be able to compete with the fierce competition we shall meet with’. Foxwell contrasted German universal banks with British banks, suggesting 'We have carried specialising, I venture to think, rather too far. Everything is specialised here', and saw value in amalgamations which would result in less specialised institutions. Stoll viewed Germany very differently, arguing that 'four great German banks ... in partnership with the German Government ... keep that [German] population in shackles more complete than was serfdom in England in the age of Feudalism' and claimed the Pujo Committee had evidenced a similar situation in the US. Committee members questioned him sceptically and appear to have largely disregarded his evidence, although the Committee Report mentions the possibility that bank amalgamations could create a 'Money Trust' in Britain.

Stoll claimed that the trend to fewer, larger banks would drive a similar trend in industry, regardless of other factors. In his view 'The hundred or so directors of five banks are more or less closely bound up with concerns in Banking, Finance, Insurance, Shipping, Railways, Mining, Electricity etc.' and would tend to favour customers with whom board links existed. The only other witness to address the question of a 'Money Trust' directly was Holden, who rubbished Stoll's argument: 'Inter-locking directors are unknown in our banking world. A director of an English 
Bank is not permitted to sit on the Board of another English Bank, and no individual or Corporation is allowed to acquire a controlling interest in their stock'. At the time of the Committee bank directors usually did not hold full-time management roles. The business, educational, social, political, marital and other family connections of bank directors undoubtedly created a loose elite of gentlemanly capitalists in the Victorian era (Braggion and Moore, 2013; Cain and Hopkins, 2002; Daunton, 1992). Recent research suggests that directors of leading banks were central to corporate networks, but that directors from non-bank financial institutions increased their presence on corporate boards as the twentieth century progressed (Wilson, Buchnea and Tilba, 2018). So while Holden may have been right about inter-bank interlocks, doubt remains about finance-industry links, or how this affected industrial finance.

Carnevali (2005) argued that some witnesses misrepresented German banking, ignoring the role of German regional banks and exaggerating the need for large banks to compete. ${ }^{26}$ Fohlin (2002, 248-251) saw strong similarities between British and German banking: similar levels of concentration from around 1890, with a surge during and after World War One, suggesting that concentration was a natural tendency in banking regardless of the dominance of universal or more specialised banks. Burhop $(2006,57)$ reinforces this view, arguing that the development of large joint-stock credit banks in Germany had beneficial effects in diversifying risk across regions and industrial sectors. As Table 1 indicates, the US was an exception, where regulation constrained branch banking and diversification, resulting in a fragmented system with thousands of unit banks, contributing to instability (Calomiris and Haber, 2014). 


\section{Conclusions}

The discussion and the findings of the Committee reveal that the banking sector that had emerged by 1918 had reached a level of systematic maturity, with many essential features that endure into the present. The sector was dominated by a small number of large banks formed from amalgamations. As such, the development of the system exhibited hysteresis - there could be no return to the system as it had been composed in the nineteenth century. However, the secular process that had led to that position in turn aroused policy-concerns about the desirability and efficacy of a consolidated and concentrated banking system, and it was these that the Committee sought to address.

The discourse of the Committee reveals that the British banking sector had changed. The simultaneous expression of both too-big-to-fail and too-small-to-survive arguments in relation to bank size, concerns about declines in capital ratios, alongside the implicit-and to some extent explicit - acknowledgement that the state (government and Bank of England) was the ultimate guarantor of the system were indicative of awareness of that change - and reflected some concern about its implications. This reveals an awareness of the moral-hazard concerns that persist into the present in relation to who carries the systemic risks of a banking sector dominated by a small number of systemically-important large banks.

The arguments for big banks were given as scalar benefits, greater managerial depth, enhanced services for industrial clients, enhanced competition, national rather than regional coverage and international competitiveness. These were set against the 
inverse for small banks: they lacked scale, managerial depth, and national coverage (but rather operated cosy regional oligopolies/cartels), could not offer services clients needed, and were not internationally competitive. For some witnesses amalgamation was necessary to rescue small banks, and was also the easiest means of expansion for larger banks. These arguments were, at one level, entirely self-serving since they represented the organisational rationale for many of the larger banks. However, they also reflected the ways in which the sector had developed. This shows the ways in which historical actors operate within a bounded episteme: this was the world as they understood it to be, but also revealed that the sector had reached a saturated level of concentration.

There is nuance in understanding what the interests of bankers and banks might be, individually and collectively. Even though further amalgamation might benefit a bank (or banks) that might become even bigger, it would potentially lead to a monopoly seen as undesirable from a free-market perspective and stimulate calls for nationalisation by a future socialist Labour government-something that the financial elites certainly wished to forestall. So the Committee did arrive at conclusions that were not unequivocally in the interests of bankers. Any further mergers in the sector were to be approved by the Treasury and the Board of Trade, thereby terminating the amalgamation movement as an organic and unregulated process. Thereafter, any amalgamations took place within a governmental and regulated context. This substantial change reflected a turn away from laissez faire and towards more interventionist roles for both government and also, in a supervisory context, the Bank of England. As such, the banks now accepted limits on their actions. 


\section{References}

Acheson, G.G. and J.D. Turner. "The Death Blow to Unlimited Liability in Victorian Britain: The City of Glasgow Failure.” Explorations in Economic History 45, no. 3 (2008): 235-253.

Ackrill, M. and L. Hannah. Barclays: The Business of Banking 1690-1996.

Cambridge: Cambridge University Press, 2001.

Alhadeff, D.A. Competition and Controls in Banking: A Study of the Regulation of Bank Competition in Italy, France and England. Berkeley, CA: University of California Press, 1968.

Allen, F. and D. Gale. Comparing Financial Systems. Cambridge, MA: MIT Press, 2000.

Anonymous, Bankers Almanac Volume 5, no.1: 2009.

Arestis, P., G. Chortareas and G. Magkonis. “The Financial Development and Growth Nexus: A Meta-Analysis.” Journal of Economic Surveys 29, no. 3 (2015): $549-565$.

Baker, M. and M. Collins. “English Commercial Bank Stability, 1860-1914.” Journal of European Economic History 31, no. 3 (2002): 493-512.

Barnes, V. and L. Newton. "How Far does the Apple Fall from the Tree? The Size of English Bank Branch Networks in the Nineteenth Century.” Business History 60, no. 4 (2018): 447-473.

Berger, A.N., L.F. Klapper and R. Turk-Ariss. “Bank Competition and Financial Stability.” Journal of Financial Services Research 35, no. 2 (2009): 99-118.

Best, M.H. and J. Humphries. “The City and Industrial Decline.” In The Decline of the British Economy, edited by B. Elbaum and W. Lazonick, 223-239. Oxford: Clarendon Press, 1986. 
Billings, M. and F.H. Capie. “Financial Crisis, Contagion, and the British Banking System between the World Wars.” Business History 53, no. 2 (2011): 193215.

Bond, I. “The British Banking Population: 1790-1982.” In Complexity and Crisis in the Financial System: Critical Perspectives on the Evolution of American and British Banking, edited by M. Hollow, F. Akinbami and R. Michie, 85-117. Cheltenham: Edward Elgar Publishing, 2016.

Braggion, F., N. Dwarkasing and L. Moore. “Nothing Special About Banks: Competition and Bank Lending in Britain, 1885 to 1925.” Review of Financial Studies 30, no. 10 (2017): 3502-3537.

Braggion, F. and L. Moore. “The Economic Benefits of Political Connections in Late Victorian Britain.” Journal of Economic History 73, no. 1 (2013): 142-176.

Burhop, C. “Did Banks Cause the German Industrialisation.” Explorations in Economic History 43, no. 1 (2006): 39-63.

Button, R., S. Knott, C. Macmanus and M. Willison. “Desperate Adventurers and Men of Straw: The Failure of City of Glasgow Bank and its Enduring Impact on the UK Banking System.” Bank of England Quarterly Bulletin 55, Quarter 1 (2015): 23-35.

Cain, P.J. and A.G. Hopkins. British Imperialism 1688-2000. London: Pearson Education, 2002.

Calomiris, C.W. and S. Haber. Fragile by Design: The Political Origins of Banking Crises and Scarce Credit. Princeton, NJ: Princeton University Press, 2014. Capie, F.H. “Trust, Financial Regulation, and Growth.” Australian Economic History Review 56, no. 1 (2016): 100-112. 
Capie, F.H. and M. Collins. "Banks, Industry and Finance 1860-1914.” Business History 41, no. 1 (1999): 37-62.

Capie, F.H. and M. Collins. "Organisational Control and English Commercial Bank Lending to Industry in the Decades Before World War One.” Revista de Historia Económica 1 (1999): 187-210.

Capie, F.H. and G. Rodrik-Bali. “Concentration in British Banking, 1870-1920.” Business History 24, no. 3 (1982): 280-292.

Capie, F.H. and A. Webber. A Monetary History of the United Kingdom, 1870-1982: Volume 1 Data, Sources, Methods. London: George Allen \& Unwin, 1985.

Carlin, W. and C. Mayer. “Finance, Investment, and Growth.” Journal of Financial Economics 69, no. 1 (2003): 191-226.

Carnevali, F. Europe's Advantage: Banks and Small Firms in Britain, France, Germany and Italy since 1918. Oxford: Oxford University Press, 2005.

Chandler, G. Four Centuries of Banking. Volume 2: The Northern Constituent Banks. London: B.T. Batsford Ltd, 1968.

Chennells, L. and V. Wingfield. “Bank Failure and Bail-in: An Introduction.” Bank of England Quarterly Bulletin 55, Quarter 3 (2015): 228-241.

Collins, M. “English Bank Development Within a European Context, 1870-1939.” Economic History Review 51, no. 1 (1998): 1-24.

Collins, M. and M. Baker. "English Commercial Bank Liquidity, 1860-1913.” Accounting, Business and Financial History 11, no. 2 (2001): 171-191.

Collins, M. and M. Baker. "Sectoral Differences in English Bank Asset Structures and the Impact of Mergers, 1860-1913.” Business History 43, no. 4 (2001): 1-28.

Collins, M. and M. Baker. Commercial Banks and Industrial Finance in England and Wales, 1860-1913. Oxford: Oxford University Press, 2003. 
Craig, F.W.S. British General Election Manifestos, 1918-1966. Chichester: Political Reference Publications, 1970.

Crick, W.F. and J.E. Wadsworth. A Hundred Years of Joint Stock Banking. London: Hodder and Stoughton, 1936.

Daunton, M. “Financial Elites and British Society, 1880-1950.” In Finance and Financiers in European History, 1880-1960, edited by Y. Cassis, 121-146. Cambridge: Cambridge University Press, 1992.

Davis, J. "Webb [née Potter], (Martha) Beatrice (1858-1943) and Sidney James Webb, Baron Passfield (1859-1947).” In Oxford Dictionary of National Biography, Oxford: Oxford University Press, online edition, 2004, http://www.oxforddnb.com/view/article/36799, accessed 3 May 2017.

Dymski, G.A. "Financial Mergers and Acquisitions: From Regulation to Strategic Repositioning to Geo-economics.” In The Oxford Handbook of Mergers and Acquisitions, edited by D. Faulkner, S. Teerikangas and R.J. Joseph, 566-592. Oxford: Oxford University Press, 2012.

Elbaum, B. and W. Lazonick. “The Decline of the British Economy: An Institutional Perspective.” Journal of Economic History 44, no. 2 (1984): 567-583.

Elbaum, B. and W. Lazonick. “An Institutional Perspective on British Decline.” In The Decline of the British Economy, edited by B. Elbaum and W. Lazonick, 117. Oxford: Clarendon Press, 1986.

Fohlin, C. "The Balancing Act of German Universal Banks and English Deposit Banks, 1880-1913.” Business History 43, no. 1 (2001): 1-24.

Fohlin, C. "Regulation, Taxation and the Development of the German Universal Banking System, 1884-1913.” European Review of Economic History 6, no. 2, (2002): 221-254. 
Fohlin, C. "Financial Systems.” In Handbook of Cliometrics, edited by C. Diebolt and M. Haupert, 393-430. Berlin, Heidelberg: Springer-Verlag, 2016.

Garnett, P., S. Mollan and R.A. Bentley. “Complexity in History: Modelling the Organisational Demography of the British Banking Sector.” Business History 57, no. 1 (2015): 181-201.

Garnett, P., S. Mollan and R.A. Bentley. "Banks, Births, and Tipping Points in the Historical Demography of British Banking: A Response to J.J. Bissell.” Business History 59, no. 5 (2017): 814-820.

Gerschenkron, A. Economic Backwardness in Historical Perspective: A Book of Historical Essays. Cambridge, MA: Harvard University Press, 1962.

Goetz, J.C., L. Laeven and R. Levine. "Does the Geographic Expansion of Banks Reduce Risk?” Journal of Financial Economics 120, no. 2 (2016): 346-362.

Goldsmith, R.W. Financial Structure and Development. New Haven, CT: Yale University Press, 1969.

Gregory, T.E. The Westminster Bank: Through A Century, Volume II. London: Westminster Bank Limited, 1936.

Grieves, K. “Mackay, James Lyle, first Lord Inchcape (1852-1932).” In Oxford Dictionary of National Biography, Oxford: Oxford University Press, online edition, 2008. http://www.oxforddnb.com/view/article/34741, accessed 23 December 2016.

Grossman, R.S. “The Shoe That Didn’t Drop: Explaining Banking Stability During the Great Depression.” Journal of Economic History 54, no. 3 (1994): 654 682. 
Grossman, R.S. "Rearranging Deck Chairs on the Titanic: English Banking Concentration and Efficiency, 1870-1914.” European Review of Economic History 3, no. 3 (1999): 323-349.

Grossman, R.S. Unsettled Account: The Evolution of Banking in the Industrialized World since 1800. Princeton: Princeton University Press, 2010.

Grossman, R.S. and M. Imai. “Contingent Capital and Bank Risk-Taking among British Banks before the First World War.” Economic History Review 66, no. 1 (2013): 132-155.

Hannah, L. The Rise of the Corporate Economy. Second edition, London: Methuen \& Co., 1983.

Hannah, L. "Banks and Business Finance before 1914: A Comparative Evaluation.” In People, Places and Business Cultures: Essays in Honour of Francesca Carnevali, edited by P. Di Martino, A. Popp and P. Scott, 75-97. Woodbridge: The Boydell Press, 2017.

Hennessy, E. A. A Domestic History of the Bank of England 1930-1960. Cambridge: Cambridge University Press, 1992.

Ingham, Geoffrey K. Capitalism Divided? The City and Industry in British Social Development. London: Macmillan, 1984.

Jones, G. British Multinational Banking 1830-1990. Oxford: Oxford University Press, 1993.

Kynaston, D. The City of London: Volume III, Illusions of Gold 1914-1945. London: Chatto and Windus, 1999.

Larson, M.J., K. Ward and J.F. Wilson. “Banking from Leeds, not London: Regional Strategy and Structure at the Yorkshire Bank, 1859-1952.” Accounting, Business and Financial History 20, no. 2 (2010): 117-133. 
Lehmann, S.H. “Taking Firms to the Stock Market: IPOs and the Importance of Large Banks in Imperial Germany, 1896-1913.” Economic History Review 67, no. 1 (2014): 92-122.

Levine, R. "Financial Development and Economic Growth: Views and Agenda.” Journal of Economic Literature 35, no. 2 (1997): 688-726.

Levine, R. "Bank-Based or Market-Based Financial Systems: Which is Better?” Journal of Financial Intermediation 11, no. 4 (2002): 398-428.

Levine, R. and S. Zervos. "Stock Markets, Banks and Economic Growth.” American Economic Review 88, no. 3 (1998): 537-558.

Moore, Christine. “The Bankers’ Almanac Register of Bank Name Changes \& Liquidations: Amalgamations, Absorptions, and Liquidations of International Banks since 1750.” The Bankers’ Almanac. London: Reed Information Services, 1992.

Newton, L.A. "Regional Bank-Industry Relations during the Mid-Nineteenth Century: Links Between Bankers and Manufacturing in Sheffield, c. 1850 to c.1885.” Business History 38, no. 3 (1996): 64-83.

Newton, L. “Government, the Banks and Industry in Inter-war Britain.” In Business and Politics in Europe, 1900-1970: Essays in Honour of Alice Teichová, edited by T. Gourvish, 145-168. Cambridge: Cambridge University Press, 2003.

Newton, L. “The Birth of Joint Stock Banking: England and New England Compared.” Business History Review 84, no. 1 (2010): 27-52.

Nicholls, David. "Fractions of Capital: The Aristocracy, the City and Industry in the Development of Modern British Capitalism.” Social History 13, no. 1 (1988): 71-83. 
O’Sullivan, M.A. Dividends of Development: Corporate America: Securities Markets in the History of US Capitalism, 1866-1922. Oxford: Oxford University Press, 2016.

Peden, G.C. The Treasury and British Public Policy, 1906-1959. Oxford: Oxford University Press, 2000.

Peters, John. "The British Government and the City-Industry Divide: The Case of the 1914 Financial Crisis.” Twentieth Century British History 4, no. 2 (1993): 126148.

Rajan, R.G. and L. Zingales. "Financial Dependence and Growth.” American Economic Review 88, no. 3 (1998): 559-586.

Ross, D.M. “The Clearing Banks and Industry - New Perspectives on the Inter-war Years.” In Capitalism in a Mature Economy: Financial Institutions, Capital Exports and British Industry, 1870-1939, edited by J.J. van Helten and Y. Cassis, 52-70. Aldershot: Edward Elgar, 1990.

Ross, D.M. “Commercial Banking in a Market-oriented Financial System: Britain Between the Wars.” Economic History Review 44, no. 2 (1996): 314-335.

Sayers, R.S. Lloyds Bank in the History of English Banking. London: Oxford University Press, 1957.

Sayers, R.S. The Bank of England 1891-1944. 3 volumes, Cambridge: Cambridge University Press, 1976.

Scott, P. and L. Newton. "Jealous Monopolists? British Banks and Responses to the Macmillan Gap during the 1930s.” Enterprise and Society 8, no. 4 (2007): 881-919.

Sykes J. The Amalgamation Movement in English Banking, 1825-1924. London: P.S. King and Son, 1926. 
Tomlinson, J. “Thrice Denied: "Declinism” as a Recurrent Theme in British History in the Long Twentieth Century.” Twentieth Century British History 20, no. 2 (2009): 227-251.

Treasury Committee on Bank Amalgamations. Report. Cmnd. 9052, Parliamentary Papers, London: His Majesty’s Stationery Office, 1918.

Turner, J.D. Banking in Crisis: The Rise and Fall of British Banking Stability, 1800 to the Present. Cambridge: Cambridge University Press. 2014.

Valickova, P., T. Havranek and R. Horvath. “Financial Development and Economic Growth: A Meta-Analysis.” Journal of Economic Surveys 29, no. 3 (2015): $506-526$.

Wilson, J.F., E. Buchnea and A. Tilba. “The British Corporate Network, 1904-1976: Revisiting the Finance-Industry Relationship.” Business History 60, no. 6 (2018): 779-806. 
Table 1: Comparative financial development, 1913

\begin{tabular}{|c|c|c|c|c|c|c|}
\hline \multirow[b]{2}{*}{ Country } & \multirow[b]{2}{*}{$\begin{array}{l}\text { Lending/ } \\
\text { GDP (\%) }\end{array}$} & \multicolumn{4}{|c|}{ Banking system characteristics } & \multirow{2}{*}{$\begin{array}{c}\text { Equity } \\
\text { market } \\
\text { development } \\
\text { (0-2 } \\
\text { subjective } \\
\text { scale) }\end{array}$} \\
\hline & & $\begin{array}{c}\text { Universal? } \\
\qquad(0-2 \\
\text { subjective } \\
\text { scale })\end{array}$ & $\begin{array}{c}\text { Bank seats } \\
\text { on } \\
\text { company } \\
\text { boards }\end{array}$ & $\begin{array}{c}\text { Equity } \\
\text { shareholdings } \\
\text { by banks }\end{array}$ & $\begin{array}{c}\text { Extensive } \\
\text { branch } \\
\text { networks } \\
(0 / 1)\end{array}$ & \\
\hline Canada & $\mathrm{n} / \mathrm{a}$ & 1 & Some & Some & 1 & 1 \\
\hline France & $16 / 29$ & 1 & 1 & Some & 1 & 2 \\
\hline Germany & 28 & 2 & 1 & Some & 1 & 2 \\
\hline Italy & 28 & 2 & Top banks & 1 & 1 & 1 \\
\hline UK/England & 33 & 0 & Few & Few & 1 & 2 \\
\hline United States & 30 & 1 & 1 & 1 & 0 & 2 \\
\hline
\end{tabular}

Source: Lending/GDP: Hannah, 2017, 85; all other data: Fohlin, 2016, 402-405, 415416 
Table 2: UK Banking in outline, 1900-1921

\begin{tabular}{|l|c|c|c|c|}
\hline \multirow{2}{*}{} & \multicolumn{2}{|c|}{ total number of UK } & \multicolumn{2}{c|}{ five largest UK banks’ percentage } \\
& \multicolumn{2}{|c|}{} & \multicolumn{2}{c|}{ share of total bank } \\
\cline { 2 - 5 } Year & joint-stock banks & bank branches & deposits & branches \\
\hline 1900 & 188 & 5,922 & 24.7 & 21.9 \\
\hline 1905 & 137 & 6,759 & 28.7 & 19.8 \\
\hline 1910 & 112 & 7,564 & 36.7 & 32.5 \\
\hline 1915 & 96 & 8,494 & 39.8 & 39.9 \\
\hline 1921 & 70 & 9,998 & 79.4 & 78.5 \\
\hline
\end{tabular}

Sources: total numbers of banks and branches: Capie and Webber, 1986, 577-578;

five largest banks: Turner, 2014, 45. Turner’s data include those banks which were wholly owned by the Big Five but remained separate entities. 
Table 3: The Committee members

\begin{tabular}{|l|l|}
\hline Name & Background \\
\hline Lord Colwyn (Chairman) & See note 9 \\
\hline Lord [Walter] Cunliffe & Governor, Bank of England, 1913-1918 \\
\hline Hon. Rupert Beckett & $\begin{array}{l}\text { Partner, Beckett \& Co., private bankers, c.1890-1921; } \\
\text { Director, London County Westminster and Parr's } \\
\text { [Westminster] Bank 1921-50, Deputy Chairman 1927-30, } \\
\text { Chairman 1930-50 }\end{array}$ \\
\hline Hon. Herbert Gibbs & $\begin{array}{l}\text { partner, Antony Gibbs and Sons; sometime member and } \\
\text { chairman of Public Works Loan Board }\end{array}$ \\
\hline Sir Arthur Haworth Bt. & $\begin{array}{l}\text { President, Manchester Liberal Federation; Liberal MP } \\
\text { Manchester South, 1906-1912, cotton yarn agent; President, } \\
\text { Manchester Royal Exchange }\end{array}$ \\
\hline Sir Richard Vassar-Smith Bt. & Chairman, Lloyds Bank, 1909-1922 \\
\hline Sir John Purcell KCB & Chairman, National Bank \\
\hline Captain H. [Henry] Keswick & Chairman, Hong Kong and Shanghai Banking Corporation \\
\hline Mr. E. [Edward] Manville & $\begin{array}{l}\text { electrical engineer and motor manufacturer with numerous } \\
\text { business interests; member Excess Profits Duty Board of } \\
\text { Referees; Unionist MP 1918-23 and member of various } \\
\text { government committees }\end{array}$ \\
\hline Mr. H. [Harry] McGowan & $\begin{array}{l}\text { Chairman and managing director, Explosives Trades } \\
\text { Limited; explosives industrialist }\end{array}$ \\
\hline Mr. John Rae & $\begin{array}{l}\text { Treasurer, Bank of Scotland; Director, Westminster Bank } \\
\text { 1926-1932 }\end{array}$ \\
\hline Mr. Douglas Vickers & Director, Vickers Limited.; armaments industrialist \\
\hline
\end{tabular}

Source: names as shown in Treasury Committee on Bank Amalgamations (1918). 
Table 4: The witnesses to the Committee

\begin{tabular}{|c|c|c|}
\hline Name & Background & $\begin{array}{l}\text { Number of pages of } \\
\text { written evidence }\end{array}$ \\
\hline Thomas Goodwin & Manager, Co-operative Wholesale Society's Bank & 10 \\
\hline Gordon Selfridge & [department store owner] & 6 \\
\hline Viscount Cowdray & [partner in S. Pearson \& Son, contractors] & 9 \\
\hline A.W. [Sir Alfred William] Flux & [Statistical Department,] Board of Trade & 11 \\
\hline Thomas Courtney Johnston & Pountney \& Co. Ltd, Bristol & 8 \\
\hline Christopher Nugent & Union Discount Company of London, Ltd. & 10 \\
\hline Sir Herbert Hambling & Chairman, London and South-Western Bank Limited & 10 \\
\hline John Ford Darling & General Manager, London Joint Stock Bank Limited & 14 \\
\hline Harold Edward Snagge & Edward Boustead \& Co., East India merchants & 5 \\
\hline Henry Bell & Director and General Manager, Lloyds Bank & 20 \\
\hline Mr. [John William] Beaumont Pease & Deputy Chairman [Chairman, 1922-1945], Lloyds Bank & 23 \\
\hline Sir James Hope Simpson & General Manager, Bank of Liverpool Ltd. & 12 \\
\hline Lord Inchcape & $\begin{array}{l}\text { Director, National Provincial and Union Bank of England, Ltd. [; } \\
\text { shipping magnate] }\end{array}$ & 13 \\
\hline Walter Leaf & Chairman, London County, Westminster and Parr's Bank, Ltd. & 9 \\
\hline
\end{tabular}


Source: TNA, T1/12267/50326, file 1 of 2; the witnesses are listed in the order in which their evidence appears on file, cross-checked against the list of witnesses in Treasury Committee on Bank Amalgamations (1918), with additional background information in parentheses. 
Figure 1: Mergers in the population of British banks, 1810-2008

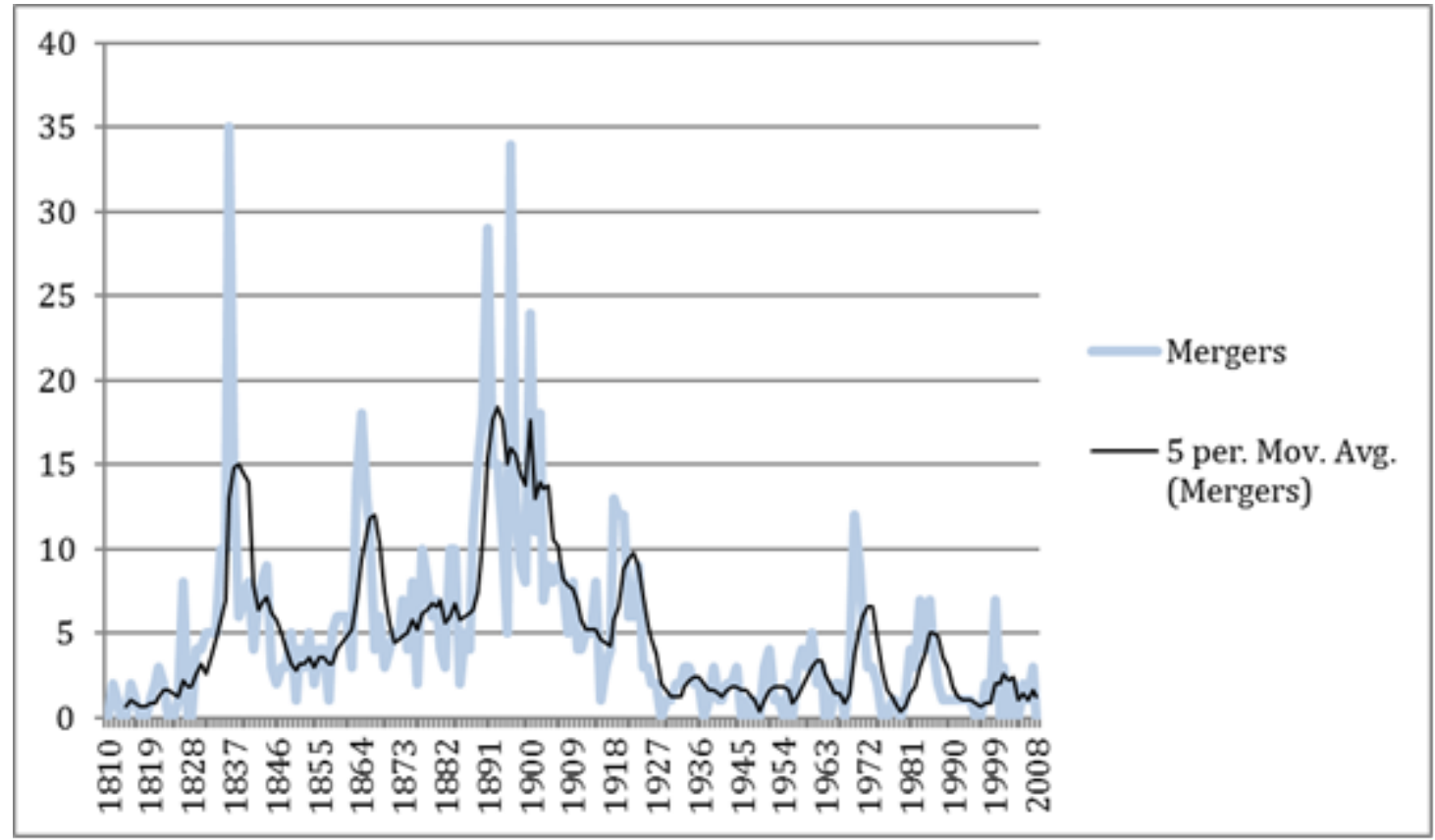

Figure 2: The population of British banks, 1924-2008 (left axis: percentage change year to year; right axis: absolute number of total banks)

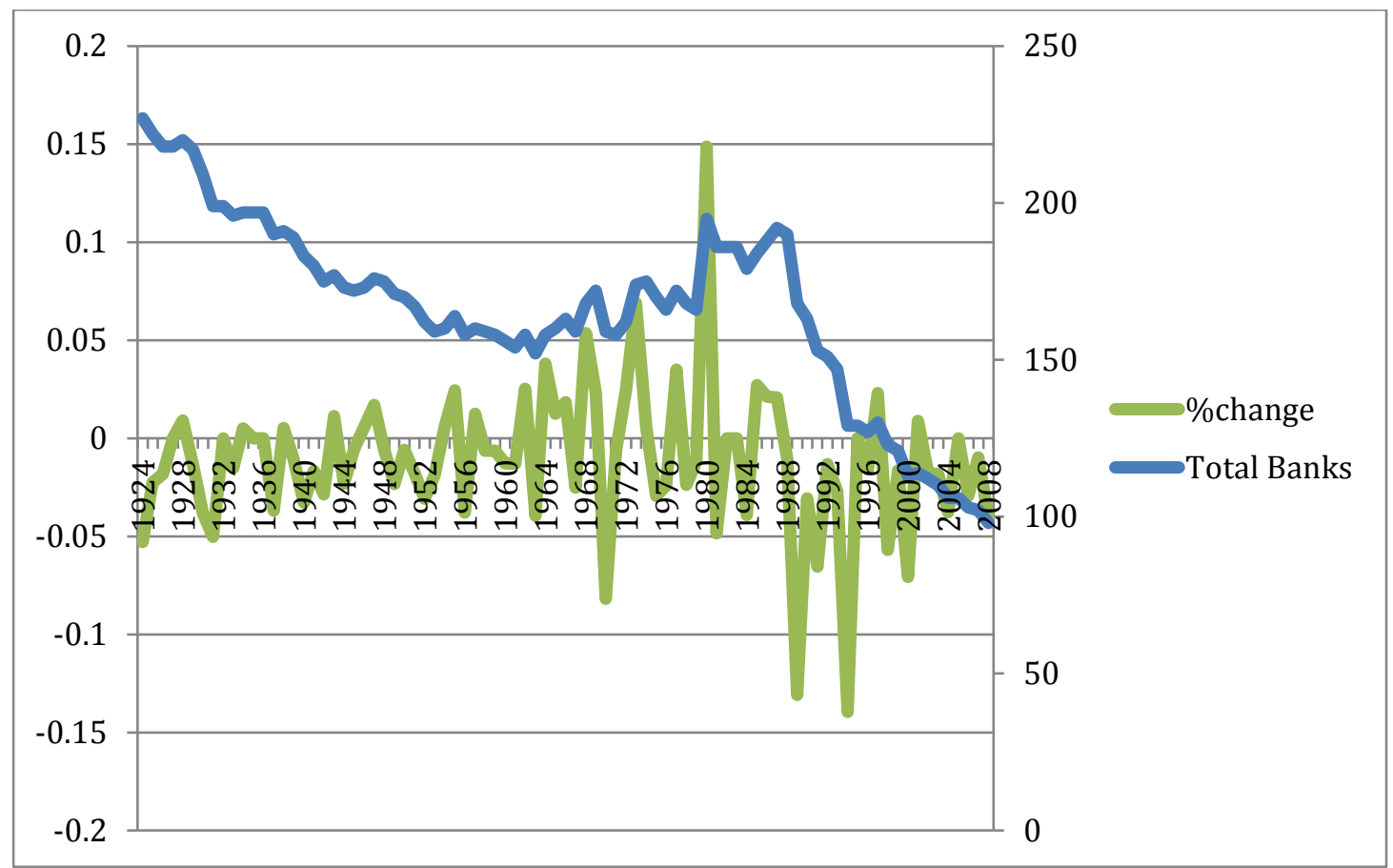


Figure 3: Mergers, creations and failures of British banks, 1880-1939 (absolute numbers)

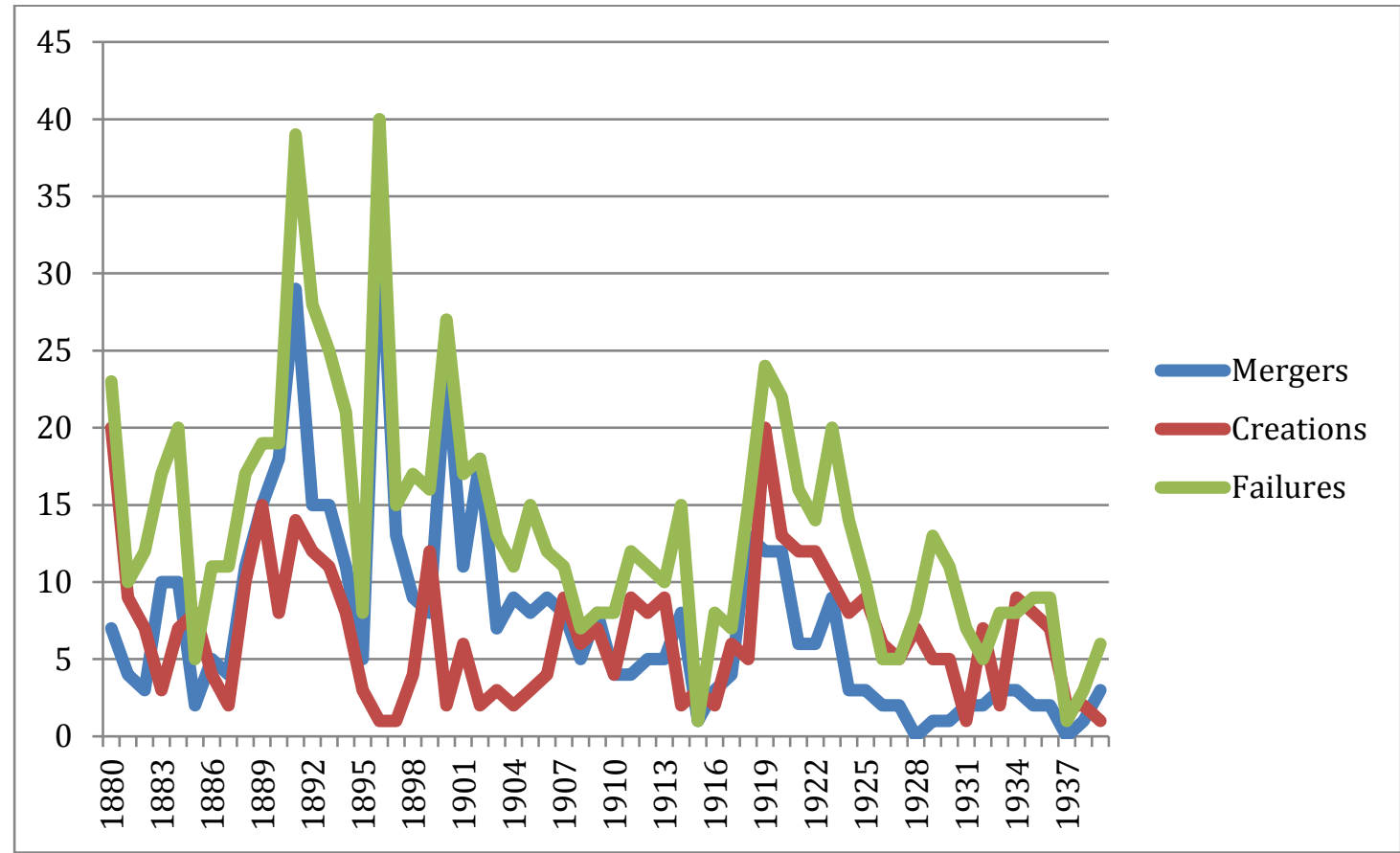

Figure 4: Mergers, creations and failures of British banks, 1880-1939 (normalised)

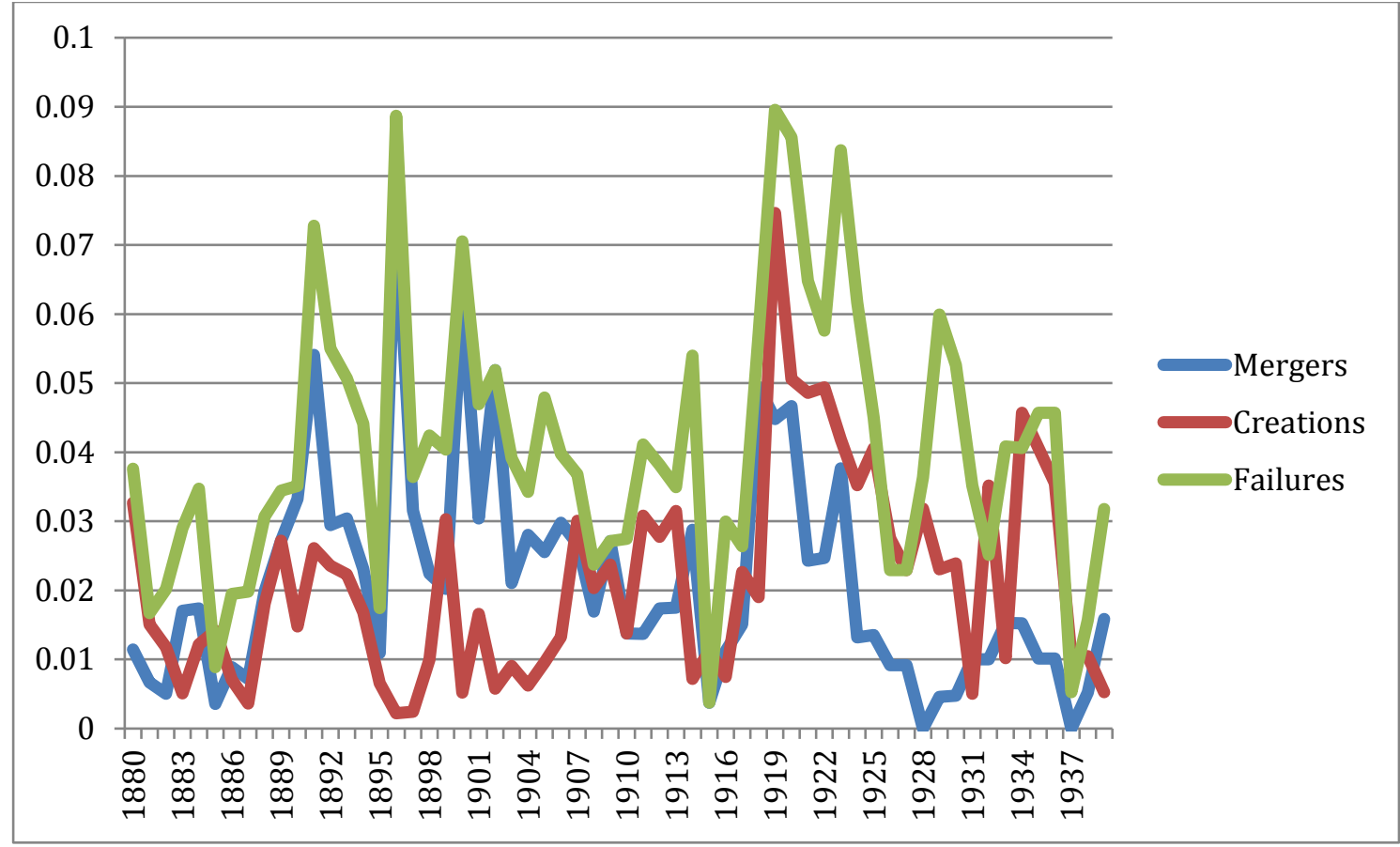


Figure 5: The population of British banks, 1810-2008

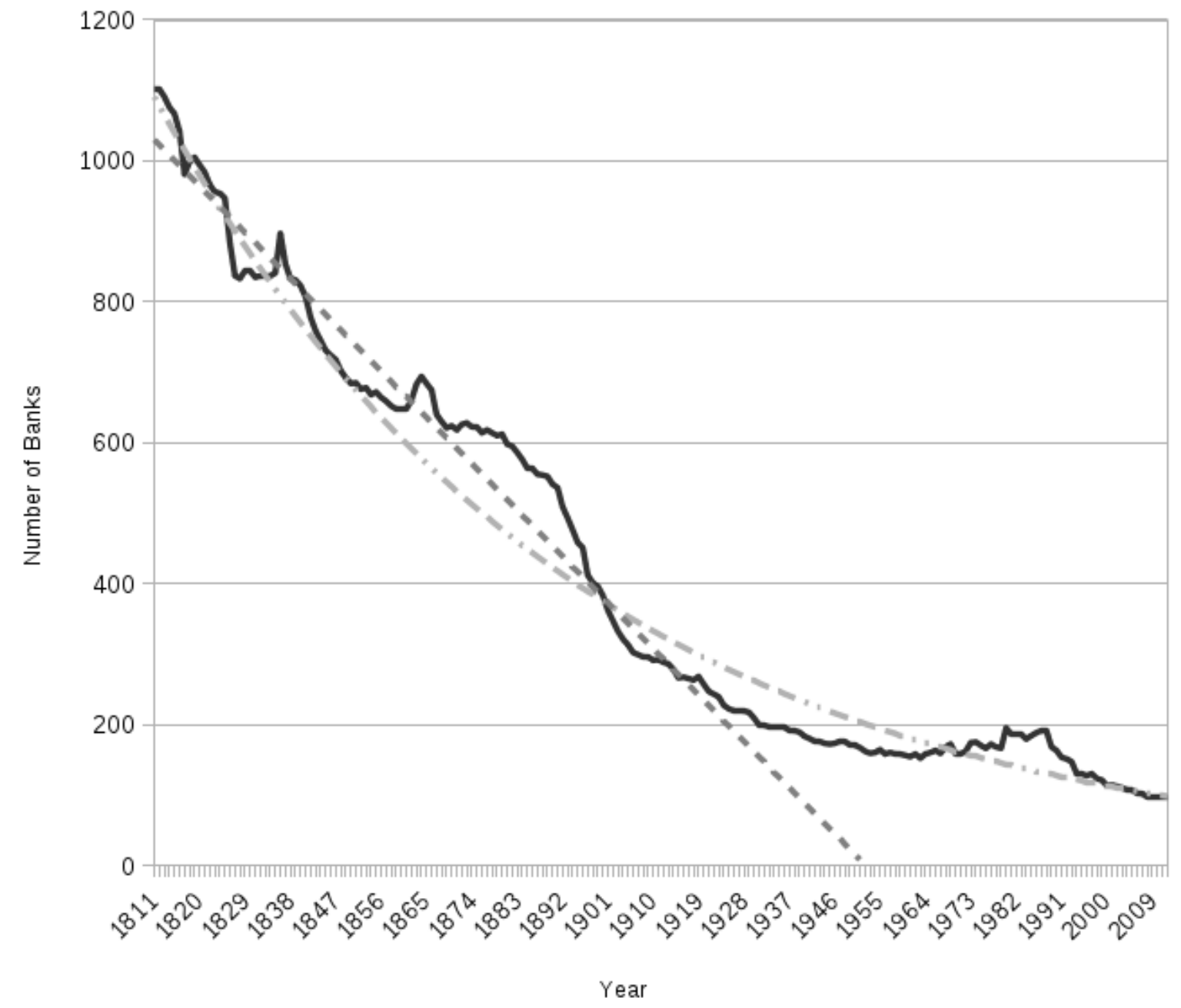


${ }^{1}$ See, for example, the recent meta-analyses of post-World War Two studies by Arestis, Chortareas and Magkonis (2015), and Valickova, Havranek and Horvath (2015). See also Fohlin (2016), 423-425 and Levine (1997).

${ }^{2}$ Levine (2002) reached a broadly similar conclusion in a study based on data from 48 countries covering the period 1980-1995.

${ }^{3}$ The banking sector was exceptional in that amalgamations proceeded earlier and more rapidly than in other sectors of the British economy. See Hannah (1983).

${ }^{4}$ The database/dataset used to construct the figures which appear in this paper is that which two of the co-authors of this paper have drawn on in two previous articles in this journal which describe the sources and methodology (Garnett, Mollan, and Bentley, 2015; 2017). These data were collected as part of the Tipping Points project at Durham University funded by the Leverhulme Trust, grant number F/00128/BF. The data sources are Moore (1992), and Bankers’ Almanac (2009). Bond (2016) presents similar data for the period 1790-1982 rather than 1810-2008. He uses similar sources but a different methodology to determine which banks to include in his data. ${ }^{5}$ For example, the head office of Lloyds was in Birmingham until 1902, with joint head offices in Birmingham and London from 1902 to 1912, and then London only from 1912 (Sayers, 1957, 261-263, 289).

${ }^{6}$ Carnevali (2005) and Scott and Newton (2007), for example, argue that banks were uncompetitive in their lending and deposit rates, were excessively conservative, failed to provide long-term capital to industry, demanded unreasonable security from borrowers, and generally exploited their 'cartel' to enjoy a quiet and comfortable life. Bur British banking enjoyed relative interwar stability when many other countries experienced severe problems: Billings and Capie (2011); Grossman (1994). 
${ }^{7}$ O’Sullivan (2016) has recently argued that evidence of a money trust in the US was exaggerated.

${ }^{8}$ Colwyn's business interests were mainly in rubber and cotton. He was a director of the Lancashire and Yorkshire Bank from 1912 and its chairman from June 1919. He was a member of various other official committees: the Treasury Committee on [wartime munitions] Contracts set up in 1918; chair of standing committees on contracts and stores established in response to that Committee's report; chair of the Royal Commission on Income Tax, 1919-20; chair of the Committee on National Debt and Taxation, set up in 1924 which reported in 1927; and chair of the 1924-5 Committee on Navy, Army, and Air Force Expenditure (Chandler, 1968, 574-575; Peden, 2000, 117; Sayers, 1976, 237).

${ }^{9}$ Webb, for example, stated in his evidence that he 'did not proffer myself as a witness'.

10 The purpose of this committee was to consider issues relating to post-World War One monetary and exchange rate arrangements.

${ }^{11}$ The typed transcripts of the witnesses' oral evidence total 280 pages and are available in the UK's National Archives. The original source of all the evidence given to the Committee is The National Archives, Kew, London (hereafter 'TNA'), file T1/12267/50326. The evidence of individual witnesses varied considerably in length: the mean page length per witness is 13 pages and the median 11 . The shortest evidence, only two pages, came from the London Stock Exchange chairman, whereas that of Sir Edward Holden runs to 34 pages. Some witnesses read a prepared statement before questioning, others simply responded to Committee members’ questions. Several (including Bell and Beaumont Pease) commented on having been called to testify at short notice, some even the same day. For most witnesses only one 
version of their evidence is on file. Occasionally a second with minor handwritten amendments can be found. There are also occasional references to unminuted confidential statements and Webb referred to having submitted a memorandum but none is on file. It is unclear why the evidence remained unpublished; the file contains correspondence with various witnesses asking them to confirm the transcripts of their evidence and whether they would object to publication. Their usual answer was that they did not.

12 TNA, T1/12313/17061 and T1/12313/17061/40169; also see discussion in Sayers, 1976, 237-241.

13 TNA, T1/12325/20697/18509; Grieves (2008). Gaspard Farrer of Barings, another Committee witness, served as an alternate to Lord Inchcape when the latter was in illhealth (TNA, T1/12325/20697/23401).

${ }^{14}$ Bank of England Archive, London (hereafter 'BoE'), G1/9.

${ }^{15}$ Ackrill and Hannah, 2001, 81-85; Jones, 1993, 141-142; Sayers, 1976, 244-245; BoE, G1/9, and G1/10; TNA, T160/711/F6070 and T160/805/F11588.

${ }^{16}$ See, for example, Berger, Klapper and Turk-Ariss (2009); Goetz, Laeven and Levine (2016).

${ }^{17}$ Carnevali (2005) regarded this argument as spurious on the grounds that, as noted in footnote 3, bank amalgamations preceded those in other sectors of the economy. ${ }^{18}$ Newton $(1996,74)$ discusses a similar example and its consequences: the heavy exposure of the Sheffield Union Bank to Naylor, Vickers \& Co.

${ }^{19}$ His own bank amalgamated with a member of the London Clearing House, Martins, in 1919.

${ }^{20}$ See Larson, Ward and Wilson (2010) on the latter. 
${ }^{21}$ See Gregory (1936, 32, 34, and 122) on the failed amalgamations of the Manchester and Liverpool District and Lloyds and the Lancashire and Yorkshire and Parr's in 1903 and 1910 respectively.

${ }^{22}$ Webb was involved in drafting the Labour party’s constitution in 1917 and wrote the party’s object (Clause IV) seeking ‘the common ownership of the means of production, distribution and exchange and control of each industry or service' (Davis, 2004).

${ }^{23}$ Webb drafted the 1918 Labour manifesto which called for land nationalisation, a capital levy and 'the immediate nationalisation and democratic control of vital public services, such as mines, railways, shipping, armaments and electric power' (Craig, 1970, 56). The party did not commit itself to the nationalisation of banks until the 1931 manifesto: 'The Labour Party is convinced, in the light particularly of experience since 1925, that the banking and credit system of the country can no longer be left in private hands. It must be brought directly under central ownership and control' (ibid., 69-70). In 1926 a private member's bill for nationalisation of the Bank of England failed (Hennessy, 1992, 206).

${ }^{24}$ Hambling was a member of the Financial Advisory Committee appointed to advise the wartime Ministry of Munitions (TNA, IR74/229).

${ }^{25}$ Turner has recently evidenced the reduction in capital as the amalgamation movement progressed (Turner, 2014, 129, Table 5.10 and 133, Figure 5.2).

${ }^{26}$ See also Lehmann (2014) on the relationship between universal banks and regional joint-stock banks in stock market IPOs. 